\title{
Emotional Intelligence in Secondary School Students
}

\author{
Biljana Bahat* \\ Faculty of Organisation Studies Novo mesto, Ulica talcev 3, 8000 Novo mesto, \\ Slovenia \\ biljana.vovk@guest.arnes.si \\ Marija Ovsenik \\ Faculty of Organisation Studies Novo mesto, Ulica talcev 3, 8000 Novo mesto, \\ Slovenia \\ mara.ovsenik@gmail.com
}

\begin{abstract}
:
Research Question (RQ): Is there any statistically significant difference between secondary school students, attending different year classes, in terms of well-being, communication and classroom relationships by incorporating emotional intelligence into everyday situations?

Purpose: The purpose of the research was to conduct an analysis among secondary school students of one of the secondary schools and to establish their experience of emotional intelligence. Students had the opportunity to be educated about emotional intelligence during preventive workshops over the past month. Method: For the purpose of the research, we conducted a quantitative analysis among randomly selected secondary school students who participated in the research voluntarily.

Results: Based on all the obtained results, we concluded that students in higher year classes were more emotionally intelligent, which contributed to better communication with each other, better relationship and well-being in the classroom.

Society: The research considered the perception of emotional intelligence among young people as an opportunity for conducting potential preventive workshops, lectures and exercises both preventively and with the inclusion of content in the regular curriculum.

Organization: Through a systematic review of the research and a review of the scientific literature in the field of emotional intelligence and adolescence, we concluded that secondary school students were familiar with this type of content and would like to include it in the study content.

Limitations / further research: The research among secondary school students of one school cannot be generalized to the entire population of secondary school students. The study also lacked year 4 students, which were represented in the minority, since Novo mesto School Center has predominantly vocational education programs, which constitute of only three years of education. Further research will follow among secondary school teachers, namely on their knowledge and use of emotional intelligence in teaching.
\end{abstract}

Keywords: emotional intelligence, adolescence, models of emotional intelligence, communication, interpersonal relationships. 


\section{Introduction}

Emotional intelligence is important in all aspects in life; it affects our health, learning and relationships (Akers, 2020, pp. 122). It covers abilities such as recognizing one's own emotional needs and restraints, encouraging oneself and addressing frustrations, controlling impulses and procrastinating with satisfaction, managing moods, releasing distress that inhibits the ability to think, empathizing with others 'emotions and developing empathy. Emotional intelligence is simply said the intelligent use of emotions. (Jeanne, 2019, pp. 10). In adolescence, which defines the developmental period between the end of childhood and start of early adulthood, i.e. between about 11-12 and 22-24 years of age, the development of intelligence is just as important as the physical development of individuals (Lansley, 2017, pp. 25).

In the research study it was intended to study how emotional intelligence in adolescents changes according to the year class in secondary school they are attending. We also wanted to find out how emotional intelligence affects well-being, relationships and communication between the students in the classroom. We predicted that older students would be more emotionally intelligent and consequently more satisfied with their well-being, relationships and communication, which we also confirmed with the research. Due to other environmental impacts, minor deviations were present.

The purpose of the research was to determine the impact of emotional intelligence on students, attending 1st to 4th year classes in secondary school and how much the use of emotional intelligence affects their relationships, communication and well-being. The aim was to determine how much the students of different year classes in secondary school know and apply the emotional intelligence and if a difference between younger and older students exist.

\section{Theoretical Framework}

Throughout the history, as well as in present time, the IQ is of great importance in assessing an individual (Krančan, 2016, pp. 22). There are many research studies related to this, many different ways and methods of measuring it, but experts and people generally realize that an individual is also shaped by something other than just the level of his intelligence in terms of understanding, mathematical abilities, making connections etc. (Krulc, 2017, pp. 427). New concepts have begun to emerge with which we can assess individual people, but they have emerged from an emotional side that is, as many say, contrary to reason.

Emotional intelligence has its roots in the concept of "social intelligence". At the time, research studies defined social intelligence as "the ability to understand and influence people and behave wisely in interpersonal relationships". This concept has long been considered as only one of the forms of intelligence. In general, many people understand emotional intelligence as a type of social intelligence that includes the ability to observe one's own emotions and the emotions of others, differentiating between them, and the ability to use this intelligence to guide thought and activity. (Salovey \& Mayer, 1990, pp. 176) The authors have already presented their views on social 
intelligence and divided it into five fields. These are: self-awareness, emotion management, selfmotivation, empathy and relationship management. The findings of these research studies prompted further studies that substantiated the belief that those leaders who manage to achieve mutual trust, respect, and a certain warmth in relationships with subordinates are more successful at leadership (Salovey and Mayer, 1990, pp. 188). To help predict their leadership performance, they tested individual's communication abilities, initiative abilities and their interpersonal relationships (Byrd, 1987, pp. 34). Categories that had greater predictive power for success than just "dry" intelligence, education or knowledge, had entered personnel policy. Despite these findings, it took a decade and more for the idea of the importance of the socio-psychological characteristics of the individual to predict his or her leadership performance to be fully established in the research and application world (Ovsenik \& Kozjek, 2017, pp. 48).

When Salovey and Mayer combined the term emotional intelligence into an uniform complex, they tried to transcend the then notion of the importance of noncognitive factors of intelligence. They described emotional intelligence as "a form of social intelligence that involves an individual's ability to perceive their own emotions and the emotions of others and the ability to separate them from each other and use that information as a guide for thinking and behaving". (Salovey \& Mayer, 1990, pp. 67)

The authors, Salovey and Mayer, were also the pioneers of research studies which aimed at developing valid instruments for measuring emotional intelligence and determining its significance. One of the first findings was that among people who watched a film that had emotionally shaken them, those who scored better on the tests of emotional intelligence were more likely to stabilize first (Mei \& Omar, 2020, pp. 478). Recent research studies, however, include findings that individuals who achieve better results on the scales of self-awareness and empathy find it easier to adapt to changes in the environment and build a solid social network around themselves more quickly (Mowat, 2019 , pp. 52 ). Goleman adopted the term emotional intelligence, incorporated it into his work, and in the early 1990s, with his book Emotional Intelligence, finally established this term set. Simultaneously, in the mentioned book, he connected the findings of social psychology, personality psychology and neuropsychology (Goleman, 1997, pp. 46). In further research studies, he focused primarily on the impact of emotional intelligence on leadership and work with people.

Pečjak and Avsec (2003, pp. 56-66) link the phenomenon of emotional intelligence to stability. They say it is in general easy to function in a stable, predictable environment. Such an environment, however, is extremely difficult to find nowadays. Everything is constantly changing. In this unpredictable environment, it is very difficult to have constant control over what is happening. Changes cause uncertainty. Emotional intelligence is a powerful source of inner stability, with which we can help each other well in a constantly changing environment. If an individual does not have good emotional competencies in a stressful world, he is easily overwhelmed by feelings of fear, hostility, insecurity, apathy, which often cause an insurmountable barrier to cooperate with other people (Jeanne, 2019, pp. 59). 
Research studies have shown that the IQ consists of the factors that determine life success, which represents $20 \%$, and the remaining $80 \%$ of emotions (Pekaar, 2018, pp. 222-233). In other words, individual uses two types of mind: rational and emotional. The rational mind, which thinks, analyzes, and concludes on the basis of objective facts, is logical in the "grounded." The emotional part is fast, impulsive, intuitive, forcing individual to act before he/she can even think about it. Sometimes it gives a distorted picture of reality, which is guided by selective memory, and sometimes it is a source of self-justification and rationalization. However, a well-managed emotional mind provides energy for a lot of work. The ones the rational mind sees as "not worth it". Therefore, we can say that the most beautiful human virtues reside in it: sacrifice, selflessness, nobility, generosity. Intelligent behavior depends on the harmony of these two minds. In everyday situations, they are balanceed, but the unforeseen life circmustances act firstly with the emotional mind. (Udovč, 2018, pp. 24-26)

Over time, many different definitions of emotional intelligence have evolved, and due to the rapidly growing field of research, authors are constantly supplementing and correcting their definitions, so to date three models of this concept have emerged: the ability-based model of emotional intelligence, the mixed model, and the emotional intelligence model, based on characteristics. (Žagar, 2018, pp. 79)

Salovey and Mayer (1990, pp. 256) strived to define emotional intelligence within the standard of criteria for new intelligence. Their initial definition of emotional intelligence was the ability to perceive emotions; emotions for including thoughts, emotion regulation. In the ability model, emotional intelligence is defined as the mental ability to meet traditional intelligence standards (Zalokar, 2019, pp. 17).

The ability model of emotional intelligence contains the following types of abilities:

- Perception of emotions: The ability to detect emotions on the face, images, voices, including the ability to recognize one's own emotions. Emotion perception is a fundamental aspect of emotional intelligence.

- Use of emotions: The ability to exploit emotions to facilitate various cognitive activities such as thinking and problem solving.

- Understanding emotions: The ability to understand the language of emotions. Understanding emotions, for example, includes the ability to be sensitive to slight differences between emotions and the ability to recognize and describe how emotions develop through learning.

- Emotion management: The ability to regulate emotions in oneself as well as in others. An emotionally intelligent person exploits emotions, even negative ones, to achieve goals. (Zalokar, 2019, pp. 17)

Futhermore, the characteristic model of emotional intelligence encompasses several different fields or components, namely adaptability, assertiveness, perception of emotions (one's own and others'), expression of emotions, control of one's own emotions, control of emotions of others, impulsivity, interpersonal relationships, self-confidence, self-motivation, sociability, stress management, 
empathy, happiness and optimism (Furnham, 2012, pp. 18). The characteristics-based model defines emotional intelligence as a combination of behavioral tendencies and self-perception of one's own ability to recognize, design, and exploit emotionally open information and should be measured by self-assessment tests (Raccanello, 2020, pp. 14).

Goleman (2017, pp. 87) set a framework for working with people to understand the impact of selfawareness, self-control, social awareness, and social competencies on work success. The model is based on emotional competencies, which the author defines as "a learned ability based on emotional intelligence that manifests itself as exceptional performance at work". Goleman tries to substantiate the foundations of emotional competence with classical psychological research methods. He states, that it is only possible to develop above-average emotional competencies when an individual has good background emotional intelligence. Here he has somehow upgraded and changed his original claims that it is possible to influence a change in emotional intelligence. Emotional competencies can be influenced on and learned, and emotional intelligence remains the foundation or potential that enables such learning. Emotional competencies are therefore competencies that we need to learn. Emotional intelligence, however, is an ability that is needed, but it is not enough to develop these competencies. Namely, an individual may have excellent abilities for spatial representations, but if he/she has never heard anything about geometry, he/she will not be able to solve even a simple geometric problem. (Goleman, 2017, pp. 98)

Adolescence is a developmental period between the end of childhood and the beginning of early adulthood, i.e. between approximately 11-12 and 22-24 years of age. This developmental period begins with prepuberty and puberty, a period of accelerated physical development, including the development of reproductive maturity following intense physical growth, and continues into the early twenties. Although prepuberty and puberty originally refer only to biological changes, we also use this term in developmental psychology to express accompanying psychological changes (Panju, 2010, pp. 56). To determine the upper limit of adolescence in modern societies, we use one or more of the following criteria: legal, sociological (end of the period in which the individual has an undefined social role), economic (economic independence from the primary family) and psychological, which is also used in development psychology, i.e. solving the developmental tasks of adolescence, achieving relative cognitive, emotional, social and moral maturity. With the development of modern society, the boundaries of adolescence gradually moved upwards, as individuals, on average, met the already mentioned criteria (with the exception of the legal one) later in life. Due to the specificity of individual subperiods within adolescence, we divide adolescence into early adolescence (up to 14 years of age), middle adolescence (up to 17 or 18 years of age), and late adolescence (up to 22 or 24 years of age). (Braun, 2020, pp. 101-151) With increasing adolescent age, the boundaries between adolescence and early adulthood are becoming increasingly loose, as individual differences between individuals in terms of achieving relative psychological maturity, completing education, and achieving economic independence are also relatively large.

Zalokar Divjak (2019, pp. 17) describes adolescence as a developmental period in which emotional lability and intensity of both experiencing and expressing emotions increase. Compared to the 
emotions of adults, the adolescent's emotions are less stable in the short term, but relatively more so than in children in late childhood, the same applies for the intensity of the emotional response. In absolute terms, more frequent mood swings can be observed among adolescents than in children, but when situational mobility is monitored, more relative mood constancy is observed among adolescents. Mood fluctuations are directly related to situational changes, but only indirectly to hormonal ones, while the quality of mood (positive, negative) regardless of the age of individuals is related to the quality of daily or important life events. (Chacón Cuberos, 2019, pp. 23)

Modern studies on representative samples of adolescents only generally find that positive emotional states on average strongly predominate over negative ones. Among the positive emotions, adolescents experience states of joy in situations in which they consider that they have adapted well, included in them, when they perform a valued activity in a group, while performing activities through which they release energy, while playing, engaging in leisure activities, social situations that they perceive as funny, in situations of socializing with others that express joy, in situations where they are aware that others are fond of them, love them, accept them, approve of them, and respect them. In adolescence, individuals also experience and express strong positive emotions towards peers of the opposite sex for the first time (Zhoc, 2020, pp. 839-863).

We set the following hypotheses:

Hypothesis 1: There is a statistically significant difference between first and fourth year class students in secondary school in achieving a high level of emotional intelligence.

Hypothesis 2: There is a statistically significant difference between students who have a higher degree of emotional intelligence and are therefore more satisfied, motivated, and successful.

\section{$3 \quad$ Methods}

In Novo mesto School Center, 734 students attending year 1 through year 4 in secondary school participated in the research. Students of the Novo mesto School Center were attending either vocational seconardy school, gymnasium, either tehnical secondary school, all part in Novo mesto School Center. The obtained results were statistically processed in accordance with the purposes and predictions of the research. All statistical analyzes were performed with the help of the SPSS/PC statistical software package. Differences between groups were calculated by analysis of variance.

In the first part of the questionnaire, where we collected demographic data, we determined the general characteristics of the participants, such as their gender, age and year class of secondary education. We used the questionnaire Multifactor Emotional Intelligence Scale - MEIS, which includes 15 fields of emotional intelligence, namely: expression of emotions, empathy, self-motivation, control of oneself's emotions, happiness, sociability, impulsivity, emotion perception, assertiveness, optimism, managing the emotions of others, interpersonal relationships, adaptability, stress management and self-confidence. Each statement had to be evaluated on a five-point Likert scale (1- I do not agree at all; 2 - I do not agree; 3 - I neither agree nor disagree; 4 -I agree; 5 - I completely agree) in order to to learn how students assess well-being and interpersonal relationships in the classroom. 
Data collection was carried out by distributing the questionnaires to the participants, asking them to participate, explaining the purpose of the research and limiting the solving time to 20 minutes. The research was conducted from 1. December to 10. October 2020. Based on a structured questionnaire, most of the questions were closed-ended. To evaluate the questionnaire, we used the key for evaluating the answers, which is an integral part of the questionnaire.

\section{Results and discussion}

Variables used in the study were personality traits and emotional intelligence. In the T-test, we measured two groups and whether the averages of a variable differed significantly. We calculated the p-value. If it was greater than 0.05 , then they did not differ significantly or the difference was not statistically significant. If it was between 0.000 and 0.05 , then they were significantly different and the difference was statistically important. So, the closer the p-value was to 0 , the greater the differences, and the threshold for the statistical characteristic was at 0.05 .

The correlation between two variables was always between -1 and 1 . If it was between 0 and 1 , the connection was positive; that is, as one variable increases, so does the other. If it was between - 1 and 0 , the connection was negative. This means that if one increases, the other decreases. If it was 1 , then they were the same, if it was -1 , then one was a flat mirror image of the other. If it was 0 , then there was no connection between them. The correlation coefficient was always the Pearson coefficient, which represented the magnitude of the linear correlation of the variables $\mathrm{x}$ and $\mathrm{y}$ measured on the same object of study. The coefficient was defined as the sum of all products of standard deviations (how dispersed were the values contained in the population) of both values in relation to degrees of freedom or as the ratio between covariance (which determined how two random variables are related) and the product of both standard deviations.

The following paragraphs represented tested hypotheses and compared them with the results.

Hypothesis 1: There is a statistically significant difference in 1st and 4th year class students in achieving a high level of emotional intelligence.

We conducted a T-test of independent samples for the first and fourth year class students in secondary school and the difference in averages existed, the p-value was 0.001 . This represented a statistically significant difference. The result was positive, because if we know that emotional intelligence develops and learns throughout life, we could state that teachers carry out their mission with a great amount of emotional intelligence that they pass on to students (Table 1).

While it is true that some people are more emotionally intelligent by nature than others, we know that we can develop a high level of emotional intelligence even if we do not have it at birth. Part of this puzzle is the personality that defines each of us (Krulc, 2017, pp. 28). Our personality is the result of our qualities, what is our tendency to introvent or extravent. But just like rational intelligence, neither the personality is a criterion for predicting emotional intelligence (Goleman, 2017, pp. 22). The personal development of children between the ages of 15 and 18, which was the sample of students included in the research, is influenced by several factors, which consequently change the emotional 
intelligence of children. But from our research we can conclude that our students mature at this time and develop emotional intelligence (Table 2).

Table 1. Sample of students included in the survey of the first and fourth year class in secondary school

\begin{tabular}{lccc} 
& Group statistics \\
\cline { 3 - 4 } & Year class & $\mathrm{N}$ & Average \\
\cline { 2 - 4 } Emotional & 1 & 342 & 2,0683 \\
Intelligence & 4 & 89 & 2,1982 \\
\hline
\end{tabular}

Table 2. Emotional intelligence in first and fourth year class students in secondary school

\begin{tabular}{crr}
\hline \multicolumn{2}{c}{ T-test for equality of averages } \\
\hline $\mathrm{t}$ & $\mathrm{df}$ & $\mathrm{p}$-value \\
$-3,405$ & 429 &, 001 \\
\hline
\end{tabular}

Emotional

Intelligence

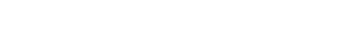

Hypothesis 1 was confirmed because the results of the research showed a statistically significant difference.

Therefore, there was a statistically significant difference between first and fourth year class students in seconardy school in achieving a high level of emotional intelligence.

Hypothesis 2: There is a statistically significant difference between students who have a higher degree of emotional intelligence and are therefore more satisfied, motivated, and successful.

We drew a correlation between the set representing emotional intelligence and the set representing motivation. The second set actually represented demotivation, as the best negative scores were measured with a score of 5 , so the correlation is expected to be negative.

The higher someone's emotional intelligence is, the less they let themselves be demotivated and distracted at work and study. The correlation size was -0.030 , very close to zero, so we concluded that there was no connection between these two sets. The Figure 1 also showed that there was no pattern. If we look at it as a whole unit, we see a cloud, and even if we look at an individual color/pattern separately, we do not see any pattern at any color. 
There were no differences between students who had a greater degree of emotional intelligence and would be therefore more motivated. We concluded that the result was due to the influence of all other factors that affect the motivation of students.

Although self-motivation is part of emotional intelligence, such as self-initiative or independence at work, in pedagogical work we observe that students who are more self-motivated need less control, lose less time, are more productive and creative.

For decades, schools have been thinking about how to motivate students, researchers are developing techniques and activities to awaken and maintain students' motivation, but from previous pedagogical experience we can say that a student is the best motivator for himself if he develops in a stimulating environment (friends, family) and starts thinking positively. (Cobos Sanchez, 2020, pp. 66) Students who are left without motivation feel lonely, dissatisfied, scared, discouraged, and anxious. From this we can conclude that a teacher who sets himself the task of motivating a student, is in an impossible role if he does not look for reasons for demotivation together with the student (Table 3).

Table 3. Correlation between motivation and emotional intelligence of 1 st to 4 th year class students

\begin{tabular}{lcc}
\hline Correlation & & \\
\hline & Motivation & $\begin{array}{c}\text { Emotional } \\
\text { intelligence }\end{array}$ \\
Motivation & 1 &,- 030 \\
Emotional intelligence &,- 030 & 1 \\
\hline
\end{tabular}

We rejected the hypothesis 2 and established:

There was no statistically significant difference between students who had a greater degree of emotional intelligence and were therefore more satisfied, motivated, and successful (figure 1). 


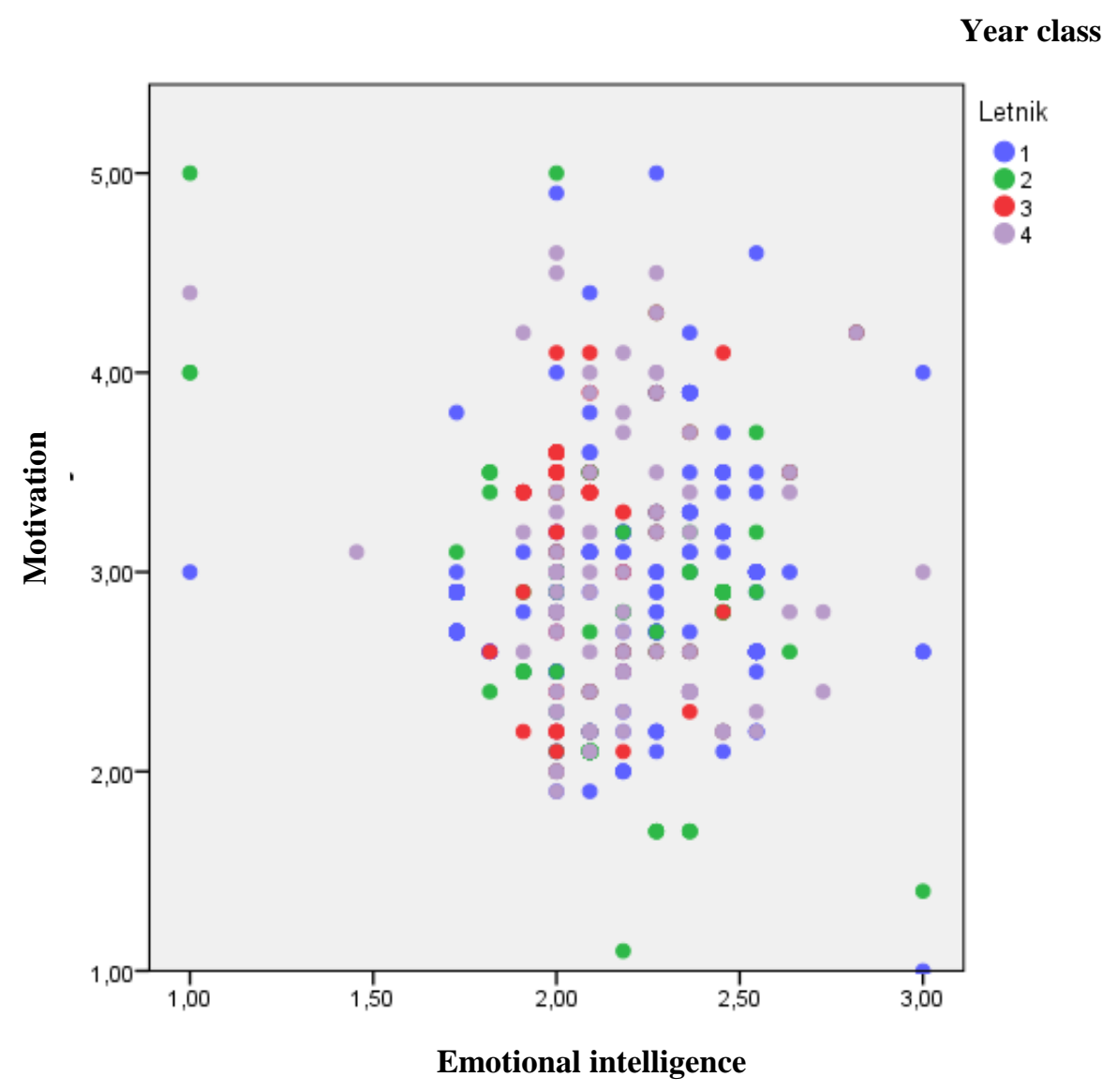

Figure 1. Correlation between motivation and emotional intelligence of first to fourth year class students in secondary school

The Slovenian secondary schools have always been focused on the rational, on testing knowledge, there is little other content. To develop other parts of a child's personality, it is not enough to change just the program. It is not possible to introduce a subject where we would learn this, explain what a human being is, what relationships are etc. The teacher can do everything with feeling. If the student connects with the teacher's way of teaching, this triggers a coordination mechanism. When a person is sensitive, the processes of self-pacification, self-awareness and motivation to learn are triggered in the brain. This has a profound effect on a person's ability to prepare for relationships and become creative, self-centered, and at the same time sensitive to others. (Carmen Martinez, 2019, pp. 55)

The teacher at the school has this nice opportunity to tell young students about things they do not see in the media and do not hear anywhere else. Therefore, the main role of the teacher, as we experience it, is that the subject is essentially an excuse to tell them things about the world that they cannot hear anywhere else, and to treat them as fellow human beings with freedom of thought and creative potential, which some students experience nowhere else but with the teacher. (Mowat, 2019, pp. 51)

I respect myself, I respect you, I am honest with myself and I am not arrogant. I'm fine, you're fine. This is a position that is really a good model. The teacher is open to different things, sets clear boundaries, and separates students from his behavior in the sense that "you are okay, but what you 
did in this situation is not okay, so I demand this and that; if you won't do it, this and that follows" (Jeriček Klanšček \& Zupančič, 2018, pp. 25-28).

The teacher is responsible for establishing a pedagogical culture in the classroom, for rationally regulating relationships, for explaining to children why he did something, in short, showing acceptance and respect, and on the other hand, strongly condemning unwanted behavior and punishes. The position "I am fine and you are fine" is very positive, both for teachers and students. To make everyone in the class feel this way, teachers can do a number of proactive things: they respect students and understand that they have the potential to be okay, they encourage them to take such a position. They should always be open to communicating with students. Students should also be allowed to take responsibility for their own learning. Teachers should praise rather than punish, prevent conflicts, if not, resolve them quickly and fairly, in short, teachers should help students develop their intellectual potential as well as their social and emotional skills (Mowat, 2019, pp. 67).

We live in a period characterized by a tendency towards quality, be it the quality of products, services or the whole life. We do not want to live in poor quality. We are sensitive to the quality that everyone defines in their own way. Everyone carries their own world of qualities (values - the world we want to live in). In this world there are images (performances): people (with whom we would like to be), things and events (which we would like to have or experience) and beliefs (social, religious and political beliefs that guide our lives). We want to work in such a way that the goals are as similar as possible to our world of qualities. Our world of qualities is therefore the most important part of our lives. This claim can be supported by the fact that we do not usually listen carefully to the people who are not in our world of qualities, we do not buy products that do not belong to it, nor do we think to bring them into it. We do not believe in ideas and do not accept values that are not in our world of qualities. (Glasser, 2007, pp. 38-40)

So, in school, a successful teacher must necessarily convince his students to bring the teacher's expectations into their world of qualities. This means that students must first accept the teacher as a personality into their world of qualities and only then can they bring in his expectations. A quality school is based on the intrinsic motivation of school staff and students. Both are internally motivated when they experience that working at school increases the quality of their lives, satisfies their needs. The realization of a pedagogical model with a desire for quality and the creation of our own quality world can be achieved through quality interpersonal relationships without external supervision, where everyone is independent and responsible for their own behavior. (Glasser, 2007, pp. 42-45)

The foundation of the teacher-student relationship is the establishment of trust between them, which means that we also teach students very early on that they must be willing to accept responsibility for their own choices. However, the teacher must learn to help the student to be able to help himself, that is, to accept responsibility for their own choices. Throughout the research, we were establishing how important the use of emotional intelligence is for the relationship with oneself and others. All of this leads us - and therefore we should all strive - to build an emotionally intelligent organization in which employees constantly use emotional intelligence capabilities in their work. Every educator must take 
responsibility for the growth of their own emotional intelligence, for the use of emotional intelligence in relations with colleagues and students. Our message is that success in our personal and pedagogical work is enormous if we use the additional skills available to us, because we can nurture, develop and increase emotional intelligence, which is therefore a quality we all have. (Valente, 2020, pp. 18-31)

\section{Conclusion}

Emotional intelligence can be studied in everyday situations, so we decided to research on emotional intelligence among young based on students' opinions about their well-being, communication and relationships in the classroom. Based on prior knowledge and known theory, we concluded that older students will be more emotionally intelligent than younger students, which we later confirmed with research. We also anticipated that relationships, communication, and classroom relationships would always be better, but we partially refuted these hypotheses with research. First-year class students were less emotionally intelligent than second-year class students, yet they were more satisfied with the well-being, communication, and relationships in the classroom. This can be justified by getting to know first-year class students between themselves, which makes them all more careful and tolerant of each other, while second-year class students already know each other better and dare to expose themselves, express their opinions and criticize, leading to conflicts and uncomfortable situations. Despite the deviation of the second year class in secondary school, we can conclude that more emotionally intelligent people are more satisfied with communication, relationships, and well-being, as this is confirmed by the pattern of the first, third, and fourth year classes. However, we can also conclude that emotional intelligence is not the only factor for people's satisfaction.

The research can contribute to a better understanding of different situations in the classroom and a better intervention of pedagogical workers in classroom situations. This will enable them to provide all young people with a good educational environment, which is the key to success.

The study lacked year 4 students, which were represented in the minority, since Novo mesto School Center has predominantly vocational education programs, which constitute of only three years of education, which should be highlighted and focused on in the future research. To further explore emotional intelligence, we suggest focusing on the question of how to increase emotional intelligence and thus improve life in society. It would be desired to explore how the emotional intelligence of adolescents is influenced by the family, the environment in which they live and the school environment where they spend the majority of their time. We believe that people are insufficiently informed on the topic of emotional intelligence and insufficiently aware of its importance and its impact on the quality of our lives.

Emotional intelligence is not something that happens only in a person's intimacy. This is a dynamic that is happening throughout society. These are the skills we learn together day in and day out, they are the values we talk about in school desks, at the kitchen table, in the staff room. The teaching community that the child observes is an example of cooperation, communication and action. The class is his second home, where he spends half a day and masters the methods of emotional survival. 
Therefore, emotional intelligence is not something that could be learned here and there for a few hours, emotional intelligence are skills, it is a way of life, action, teaching that is with us at all times. Therefore, we should strive and work towards making emotional intelligence an integral part of life and lessons and not an occasional moment of the inevitable. Let us work together in the awareness that reason and emotion are equal and need to work together mutually. Let us show children that empathy is just as valuable as great success. We also create an atmosphere in the classroom that is good, pleasant, because without warmth there cannot be any growth. If the atmosphere is cold and competitive, children grow only physically, but do not develop imagination, critical thinking, free expression without fear of experiencing criticism. The warmth comes from the indescribable multitude of events in the classroom, and its foundations are enthusiasm, liveliness and clarity. Educational work is arduous, lasting, and difficult; we must do it with affection, observation, and praise, and above all, by example.

The notion of emotional intelligence also gives rise to many different ways and approaches, which different authors want to put into practice, either in the workplace or in life in general. There are also tips or guidelines occuring, which must be followed by individuals within the organization in order for the introduced emotional intelligence to be successful and efficient (Ovsenik \& Turnšek Mikačić, 2015, pp. 234).

We conclude the article with our premise that in school, work and learning are the main task of children and not debates and joint projects of parents, teachers and children.

And this exactly is our task, to prepare the child for life, to teach him independence and responsibility and to estimate what is right and what is wrong, what is good and what is bad. 


\section{References}

1. Akers, M. (2020). What is emotional intelligence. Retrieved from https://psychcentral.com/lib/what-isemotional-intelligence-eq/ (September, 2020).

2. Braun, S. (2020). Effects of teachers' emotion regulation, burnout, and life satisfaction on student wellbeing. Journal of applied developmental psychology, 69, pp. 101-151. doi: 0193-3973.

3. Byrd, R.E. (1987). Corporate leadership skills: A new synthesis. Organizational dynamics.

4. Carmen Martinez, M. (2019). Trait emotional intelligence profiles, burnout, anxiety, depression, and stress in secondary education teachers. Personality and individual differences, vol. 142, pp. 53 -61.

5. Chacón Cuberos, R. (2019). The Relationship between Emotional Regulation and School Burnout: Structural Equation Model According to Dedication to Tutoring. International Journal of Environmental Research and Public Health, 16(23), 4703. Retrieved from: https://doi.org/10.3390/ijerph16234703. (24.11.2019).

6. Cobos Sanchez, L. (2020). Relation between psychological flexibility, emotional intelligence and emotion regulation in adolescence. Current Psychology.

7. Furnham, A. (2012). Psihologija: najpomembnejša dognanja človeštva. Maribor.

8. Glasser, W. (2007). Kako vzpostaviti učinkovit nadzor nad svojim življenjem: teorija nadzora. Ljubljana: Samozaložba. A. Urbančič.

9. Goleman, D. (1997). Čustvena inteligenca. Ljubljana: Založba Mladinska knjiga.

10. Goleman, D. (2017). Čustvena inteligenca: zakaj je lahko pomembnejša od IQ. 7th ed. Ljubljana: Mladinska knjiga.

11. Jeanne, S. (2019). Mental emotional. Retrieved from https://www.helpguide.org/articles/mentalhealth/emotional-intelligence-eq.htm (2.10. 2019).

12. Jeriček Klanšček, H. \& Zupančič T. (2018). Z zdravjem povezana vedenja v šolskem obdobju med mladostniki v Sloveniji, izsledki mednarodne raziskave HBSC. Nacionalni inštitut za javno zdravje: Ljubljana.

13. Krančan, L. (2016). Čustvena inteligenca. Retrieved from http://ww.preberite.si/custvena-inteligenca/ (3. October 2020).

14. Krulc, P. (2017). Čustvena inteligenca učiteljev. Vzgoja: revija za učitelje, vzgojitelje in starše. 19, (74), 27-28.

15. Lansley, C. (2017). Emotional intelligence-ability, trait or mixed? Retrieved from http://www.eiagroup.com/2017/07/10/emotional-intelligence-ability-trait-mixed/ (2. September 2020).

16. Mei, K. \& Omar A. K. (2020). The relationship between emotional intelligence of school principals in managing change and teacher attitudes towards change. International journal of leadership in Education, 22(4), 469-485. Retrieved from https://doi-org.nukweb.nuk.uni-lj.si/10.1080/13603124.2018.1481535. (11. September 2020).

17. Mowat, J. (2019). Supporting the transition from Primary to Secondary school for pupils with social, emotional and behavioural needs: a focus on the socio-emotional aspects of transfer for an adolescent boy. Emotional and behavioural difficulties, 24(1), 50-69. Retrieved from https://doiorg.nukweb.nuk.uni-1j.si/10.1080/13632752.2018.1564498. (3. October 2020).

18. Ovsenik, M. \& Turnšek Mikačić, M. (2015). Karierno načrtovanje: kako najti v sebi skriti zaklad? Novo mesto: Fakulteta za organizacijske študije, 2015. X, 234.

19. Ovsenik, M. \& Kozjek, D. (2017). Model dejavnikov znanja in njihov vpliv na uspeh organizacije. Zrna odličnosti fakultete za organizacijske študije v Novem mestu: Nove paradigme organizacijskih teorij, pp. 37-68. 
20. Panju, M. (2010). Strategija za spodbujanje čustvene inteligentnosti v razredu. Ljubljana: Modrijan.

21. Pečjak, S. \& Avsec, A. (2003). Konstrukt emocionalne inteligence. Psihološka obzorja, Društvo psihologov Slovenije, 12 (1), 55-66.

22. Pekaar, K. (2018). Self-and other-focused emotional intelligence: Development and validation of the Rotterdam Emotional Intelligence Scale (REIS). Personality and Individual Differences, 120, pp. 222233.

23. Raccanello, D. (2020). An intervention promoting understanding of achievement emotions with middle school students. European Journal of Psychology of Education.

24. Salovey, P. \& Mayer, L.D. (1990). Emotional intelligence. Imagination, Cognition, and Personality.

25. Udovč, G. (2018). Čustvena inteligenca in kreativnost veščini prihodnosti. HR\&M: Strokovna revija za področje razvoja organizacij in vodenja ljudi pri delu. 4, (17), 24-26.

26. Valente, S. (2020). The role of the teacher's emotional intelligence for efficacy and classroom management. Revista CES Psicología, 13(2), 18-31.

27. Zalokar Divjak, Z. (2019). Eno je inteligenca, drugo je otrokov socialni in čustveni razvoj. Brestanica: Posavski obzornik. 23, (17) (22. August 2019).

28. Zhoc, K. (2020). Emotionally intelligent students are more engaged and successful: examining the role of emotional intelligence in higher education. European Journal of Psychology of Education, 35, (4), $839-863$.

29. Žagar, T. (2018). Povezava čuječnosti in čustvene inteligence z ravnotežjem med delom in zasebnim življenjem. Univerza v Ljubljani. Ekonomska fakulteta v Ljubljani.

$* * *$

Biljana Bahat is a doctoral student at the Faculty of organisation study in Novo mesto. She is employed as a secondary school teacher in the field of social sciences, where she deals with the emotional intelligence of students and their potential, participates in international projects. Her research interests include quality classroom work, preventive workshops for students in the fields of emotional intelligence, mindfulness, sense of self worth, mental health and communication.

Marija Ovsenik is a full professor and expert in the field of organisation, people management and social gerontology. She obtained a PhD from the Faculty of Political Behavior Veljko Vlahović in Sarajevo and the Faculty of organisation study in Novo mesto, and completed a specialized training in the field of human resource management in non-profit organizations at the University of Ljubljana. In 1996, the Ministry of Labor, Family and Social Affairs awarded her the prize for outstanding achievements in the field of social protection.

\section{Povzetek: \\ Čustvena inteligenca pri srednješolcih}

Raziskovalno vprašanje (RV): Ali obstaja statistična pomembna razlika med dijaki različnih letnikov glede na počutje, komunikacijo in odnose v razredu z vključevanjem čustvene inteligence v vsakodnevne situacije?

Namen: Namen raziskave je bil narediti analizo med srednješolci ene izmed srednjih šol ter ugotoviti njihovo doživljanje čustvene inteligence. Dijaki so v preteklem mesecu imeli možnost ob preventivnih delavnicah se izobraževati o čustveni inteligenci. 
Metode: Za namen raziskave smo naredili kvantitativno analizo med srednješolci, ki so bili naključno izbrani in so prostovoljno sodelovali v raziskavi.

Rezultati: Glede na vse dobljene rezultate lahko sklepamo, da so dijaki v višjih letnikih bolj čustveno inteligentni, kar pripomore k boljši medsebojni komunikaciji, boljšemu odnosu in počutju v razredu.

Družba: Raziskava obravnava zaznavanje čustvene inteligence med mladimi kot priložnost za iskanje potencialnih možnosti za izvajanje preventivnih delavnic, predavanj in izvedbo vaj tako kot preventivno kot tudi vključevanje vsebin k rednemu učnemu načrtu.

Originalnost: $\mathrm{S}$ sistematičnim pregledom opravljene raziskave ter pregledom znanstvene literature s področja čustvene inteligence in mladostništva, smo prišli do spoznanj, da dijaki poznajo in si želijo tovrstnih vsebin vključevati k učnim vsebinam.

Omejitve/nadaljnje raziskovanje: Raziskava med srednješolci ene šole ni mogoče posploševati na celotno populacijo srednješolcev. Omejitev raziskave je tudi nesorazmerno število dijakov 4 letnika, ki so bili zastopani v manjšini. To je posledica dejstva, da Šolski center Novo mesto izobražuje pretežno dijake poklicnih programov, ki zaključijo svoje izobraževanje v 3 letnikih. Nadaljnja raziskava s tega področja bo sledila med učitelji srednjih šol in njihovega poznavanja ter uporabljanja čustvene inteligence pri poučevanju.

Ključne besede: čustvena inteligentnost, mladostništvo, modeli čustvene inteligentnosti, komunikacija, medsebojni odnosi.

Copyright (c) Biljana BAHAT, Marija OVSENIK

\section{(a) (1) ()}

Creative Commons License

This work is licensed under a Creative Commons Attribution-ShareAlike 4.0 International License. 